\title{
The Problems of Psychological Adaptation and Support of Internally Displaced First-Year Students
}

\author{
O. Lytvynenko \\ Borys Grinchenko Kyiv University \\ Corresponding author. E-mail: o.lytvynenko@kubg.edu.ua
}

Paper received 10.10.19; Accepted for publication 28.10.19.

\begin{abstract}
https://doi.org/10.31174/SEND-PP2019-207VII84-13
\end{abstract} Abstract. The article is devoted to the problem of psychological support of the first-year students, who had been internally displaced
from their native regions because of hostilities and military actions. There is presented a concept of complex psychological adapta-
tion of first-year students to the university life. Generalization of the theories of the adaptability of adolescents and the concepts of
their adaptation to the new conditions of life allowed finding some ways of this problem solving. The results of an empirical study of
the individual-psychological qualities of first-year students are presented, the features of their social interaction and academic moti-
vation are described. The article may be of interest to the practical-psychologists, counsellors, psychotherapists and educators.

Keywords: adaptation, first-year students, internally displaced people, adaptive resources, adaptive capacity, educational process.

Main text introduction. Social processes that take place in the Ukrainian society have led to the emergence of a significant number of internally displaced people. These people were forced to leave their homes and start a new life because of hostilities in their native settlements. The specifics and duration of the period of adaptation and habituation to the new conditions of life depends on numerous factors such as individual psychological peculiarities of the person, his/her adaptive resources, specifics of the functioning of the emotional and volitional sphere, integration into social and professional activities, age, sex etc. The adaptation period may be particularly traumatic for adolescents whose displacing from the native places of living coincides with entering higher educational establishments and beginning of student life. Therefore, the purposeful and organized work of various specialists (psychologists, pedagogues and tutors) is needed. Such a work is able to improve the integration of such adolescents into the students' community and to eliminate the negative manifestations associated with forced relocation.

A preliminary analysis of literature has shown that there were numerous attempts of scientific interpretation of the process of adaptation of adolescents to the studying at higher educational establishments. So F. Berezin, V. Gritsenko, J. Kleyberg, P. Kuznetsov etc. talk about the complex structure of the process of adaptation of individuals to the new conditions of life and to the new activities. The beginning of the studying at the higher education establishments is traditionally associated with the transition to a new system of social interaction. The freshmen face with a change in the traditional way of living that automatically triggers processes of adaptation. In turn, these processes are associated with solving a wide range of problems. One of the central socialpsychological problems of the process of adaptation is the mastery of a new social role - the role of a student [1]. V. Shlaina determines the adaptation of the students as a process of bringing the basic parameters of their social and personal characteristics to correspondence with a state of dynamic equilibrium with the new requirements of the environment of the higher educational institution as an external factor in relation to the student [7]. T. Chikina suggests that the adaptation of students is a complex process of psychological restructuring of personality. This process includes the changes in the various individual characteristics of people and in changing the style of interaction between them, as well as different ratios of changes in the various stages of the adaptation process [6]. From the other side, C. Ricafort, J. Rivera and B. Battad argue that the adaptation of first-year students is related to overcoming the difficulties of joining a new social environment, establishing intra-group relations, adapting to new forms of educational activity and getting used to the new way of living in general [10]. The period of adaptation to the studying is also a serious stress factor for young people. The results of the researches suggest that at this time numerous mental disorders, such as depression, social exclusion, ADHD etc. arise or become aggravated [8]. That is why first-year students need special psychological assistance. To provide them with this assistance the counsellor should be aware of the stages of the adaptation to the studying.

F. Berezovin distinguishes four stages of adaptation of the freshmen to the new way of living, to their academic group and to the new social-cultural environment [1].

1. Initial stage. The individuals are aware of the need of acting in a new social environment, but they are not yet ready to accept and recognize a new system of values of an educational institution. Therefore, they try to adhere to the usual system of values.

2. Stage of tolerance. There is a mutual tolerance to traditional patterns of behaviour and value system between the individuals, the group and the new environment.

3. Accommodation. Takes place the adoption and recognition of a system of values in the new environment by the individual. Furthermore, the individuals start to recognize the new socio-cultural environment of the values of the group that had been unfamiliar for them earlier.

4. Assimilation. The combination of the value system of the individual (group) and the environment takes place in this stage. 
Consequently, the process of adaptation to university studying is a complex system of transformations that occurs with a person in accordance with changes in living conditions. The beginning of students life is associated with numerous social changes; replacement of existing installations and stereotypes; stressful situations. For some students, this can lead to a substitute for a real sense of adolescence by such actions as the freedom to attend classes, unsystematic performance of homework, etc. All this can eventually be transformed into a negative attitude to studying, educational institution and the social functioning in general.

Such critical manifestations can be particularly acute in the life of adolescents and young people who not only changed their social status by entering the higher educational establishment but also were also forced to leave their homes due to military actions taking place in the region and have to get used to new activities in absolutely new living conditions. It is oblivious that all these people who left their homes, their native land, relatives and friends (close society) need psychological help in adapting to new living conditions [8].

Researches and practical psychologists focus on the need of the individual approach to the adaptation of internally displaced people, their active social adaptation and re-socialization, as well as the need to provide them with qualified psychological assistance [9]. Actually in this context may be outlined several functions of psychologcal assistance to the settlers. According to V.Smal and O. Pozniak, the psychological work with internally displaced people first of all serves as an intermediary between cultures and helps both society and migrants [4]. On the other hand, G. Lazos states that the question of tolerant attitude towards internal migrants is relevant for today's Ukraine, that is why the study of the experience of specialists who have been working with the problems of migrants for a long time shows that in addition to psychological support, their assistance assumes assimilation in new cultural conditions and adaptation to unusual living conditions [3].

G. Lazos distinguishes the following main functions of a psychologist who provides psychological assistance to internally displaced persons: 1) psychological adaptation (processing of heavy stress states; helping in perceiving change and returning to life; helping to assimilate and integrate the experience gained and create new life prospects); 2) social adaptation (assistance to migrants in adapting to a new environment / relocation). So, to provide complex assistance to internally displaced people and to improve their psychological well-being psychologist should take ino consideration both these factors [3].

Adaptation of internally displaced freshman students to studying should take place as an active creative adaptation of students to the conditions of higher education. This process should include the development of the skills and abilities of students in the organization of mental activities, recognition of the chosen profession, rational timing of the labour, rest and everyday life. Furthermore, they have to create their own work aimed at regular professional self-education and developing the meaningful traits and skills.

The purpose of the study was to summarize the practical experience of adapting first-year students to studying at universities with the indication of specific techniques and technologies for working with students who are internally displaced.

Materials and Methods. Thus, we can state the necessity of multidimensional work on the adaptation of internally displaced to studying at higher educational establishments. That was the aim of our research and further practical work with this category of respondents. The research was conducted at Kyiv College of Light Industry. The general number of freshmen involved into the research was 173 and $11 \%$ of them were internally displaced. So we had a possibility to analyse the differences in psychological adaptation to the studying within two samples. The age of respondents was $15-19$ years $(\mathrm{M}=16$ years); $68 \%$ of them were female and $32 \%$ were male.

Our work included three basic lines. The first line was devoted to psychological diagnostics. Within this part of work we used such psychological methods as Individually-Typological Questionnaire [5], Academic Motivation Scale was used [2], a modification of a questionnaire for identifying a social position within a group, a psychological interview, etc. The second line of work included a number of group activities and trainings aimed at psychological integration of the students and optimization of the process of their adaptation to studying. The third line was devoted to the individual counselling with the students who appealed for psychological assistance.

The results of the diagnostics were reported to each student individually, and in a generalized form, they were given to the tutors of the academic groups. Interaction with tutors is a separate important stage in the work of the psychologist, aimed at adapting the freshmen. For the productive activities of grouping together and organizing extracurricular activities of the first-year students, the tutors should be informed about the individual peculiarities, features and qualities of the students from their groups. This allows tutors to integrate everyone into the student's life of the university as efficiently as possible.

Results. According to the results of psychological diagnostics of students, using the Individually-Typological Questionnaire [5], it was found that 79\% of students belonging to the category of internally displaced have a high level of aggressiveness and $83 \%$ have a high level of sensitivity and emotionality. This may be connected with the desire of self-affirmation, activity and autonomy combined with emotional instability, vulnerability and tendency to depressive reactions to failure. According to other scales the statistically significant coincidence were not found. Besides, within the psychological interview we received the data about the general feeling of psychoemotional well-being of students, their self-esteem, the desire of social activities, interest in academic activities, etc. The results of the interviews were compared with the results of an individual-typological survey. As we have seen, there was a strong direct correlation between anxiety and law self-esteem as well as between anxiety and the quest for academic activities (high academic motivation). It means, that academic achievements help anxious students to improve their self-esteem. On the other hand, high self-esteem correlates with extraversion. So we may say, that social activitbes and communication with others allows person to feel more self-confident. In general, psychological well-being is connected with extraversion 
and spontaneity. So the respondents who have high indicators in these two scales usually overcome the process of psychological adaptation to studying much faster and easier then the others. The distribution of the results of the study of intra-group interaction corresponds to the normal distribution curve, that is, $27 \%$ of these students have a high social status in their academic groups; the status of $20 \%$ is low and $53 \%$ have social status, which can be described as average. This tendency is observed also in the analysis of the results of all the studied freshmen.

The statistical processing of the data was carried out with the help the Spirman`s ranking correlation coefficient. In order to avoid illogical or casual interactions, only correlations with a significance of $<0.01$ (that is, the most powerful) were analysed. So we should dwell on each of the 5 indicators listed in the table. Psychoemotional well-being has positive correlations with extraversion $(\mathrm{r}=0.4 ; \mathrm{p}<0.001)$ and spontaneity $(\mathrm{r}=0.24$; $\mathrm{p}<0.001)$. Low self-esteem has a positive correlation with anxiety $(\mathrm{r}=0.23 ; \mathrm{p}<0.001)$ and emotion $(\mathrm{r}=0.16 ; \mathrm{p}$ $<0.01)$ and negative correlation with aggressiveness $(\mathrm{r}=-$ $0.21 ; \mathrm{p}<0.001)$. On the other hand, high self-esteem correlates positively with extraversion $(r=0.27$; $\mathrm{p}<0.001)$ and rigidity $(\mathrm{r}=0.25 ; \mathrm{p}<0.001)$. Quest for social activities has positive correlations with extroversion $(r=0.23$; $p<0.001)$ and sensitivity $(\mathrm{r}=0.19 ; \mathrm{p}<0.01)$ and negative correlations with introversion $(\mathrm{r}=-0.22 ; \mathrm{p}<0.01)$. Quest for academic activities has a positive correlation with anxiety $(\mathrm{r}=0.21 ; \mathrm{p}<0.01)$ and a negative correlation with emotiveness $(r=-0.31 ; p<0.001)$. The long-term observation of group dynamics in the academic groups made it possible to state that the vast majority of internally displaced students tried to take administrative positions in academic groups in the early stages of interpersonal interaction (to become a senior, a head of seniority etc.). This indicates that they have such common features as purposefulness and aspiration for leadership.

However, having succeeded in getting those administrative positions quite easy, more than half of respondents (60\%) lost their interest in public activities and stopped showing the necessary initiative. As a result, by the end of academic year, they were all displaced from their positions. On the other hand, the last $40 \%$ of respondents have shown the ability to perform administrative and organizational activities, but they have achieved success not only at the level of the academic group but were also included in the social activities of the educational institution: they entered the students' council and the students' trade union, began to participate in the volunteer and charitable activities.

At the third stage of psychological diagnostics took place a definition of the structure and level of academic motivation of freshmen. The research was conducted in February-March, when the students had already completed the first session, faced the first difficulties and met the rating system of appointment of the scholarship, which became an additional frustration factor for them. According to current legislation, internally displaced students may not participate in the rating race and, in the case of positive completion of the exam session, will receive a social scholarship under any conditions. From our point of view, this is a fundamental factor that influences their academic motivation.
As a diagnostic tool, Academic Motivation Scale was used [2]. With its help, the following tendency was observed: for all students from the category of internallydisplaced a high and very high level of external motivation is characteristic. The reason of such results may be connected with the fact that they consider studying to be a way to prevent any problems. In addition, the academic achievements of such students were analysed. All of them showed medium and high levels of studying. $20 \%$ of them even were included in the general scholarship rating, which included $45 \%$ of the most successful students of their specialty.

Generally, analysing the results of the diagnostics of adaptation of first-year students, particularly of those who were internally displaced, we are able to make a conclusion that they are quite ambitious, geared towards achieving leadership positions, open to social activities. All of this may be treated as a substitute factor that compensates the loss of the habitual circle of social interaction.

Within the second part of adaptation work, there were held the group training sessions with the freshmen. The aim of the training was to familiarize students with each other and to involve them into group activity. The criteria of effectiveness there was a degree of cohesion of academic groups and the feeling of psycho-emotional comfort in learning situations. In addition, there was held a series of lessons with elements of the training aimed at the development of students' skills in self-organization and constructive learning ability.

Internally displaced students were quite actively involved in training work and tried to get as much attention as possible from a psychologist. Having established a working contact with a psychologist and feeling the trust in him, they began to be visit personal consultations. The following statistics are interesting: among the first-year students during the academic year, $19 \%$ of the individuals came to the psychologist for individual consultation. On the other hand, the number of internally displaced students who realized the need of psychological help and applied for it was $70 \%$. It means, that despite external stability and normal adaptation to learning and students' life, they are experiencing critical period that they cannot cope on without the help of the specialist.

The main reasons of applying of freshmen to a psychologist are the following: a feeling of meaninglessness of life and a depressive mood; problems in relationships with group mates; conflicts with beloved partners; difficulties in dealing with representatives of the opposite sex; unwillingness to learn and difficulties in mastering the academic material; individual fears and anxieties; the desire for self-understanding and self-examination; a desire to attract attention and be heard etc.

The main work of the psychologist was connected with emotional support and facilitation of students, elimination of the intensity of neurotic manifestations, development of interpersonal skills and looking for personal resources. In general, the process of adaptation of freshmen can be considered successful. During the school year and upon its completion, not a single student was dismissed due to debt training, or conflicts with group mates; the vast majority of students were integrated into extra-curricular activities and various types of social activity.

Discussion. Actual questions of modern Ukrainian 
psychology, is a theoretical understanding and empirical study of the adaptation of internally displaced students to study at universities.

Adaptation to training is a complex process of assimilating the norms and rules of an educational institution, establishing friendly relations with group mates and constructive relationships with teachers; development of strategies of educational activities and extra-curriculum activities.

Within the framework of our diagnostics of the adaptation of the first year students of one of the Kyiv colleges to the training, it was discovered that those freshmen that belong to the category of internally displaced demonstrate in general normal indicators of inclusion into the educational process and students' life. On the other hand, they require in a much greater degree than other students an immediate attention and psychological assistance.

The main task of a psychologist was to create safe conditions for interaction with such students; help them to release their emotions and to remove psycho-emotional stress, to find the meaning of being and to formulate longterm goals, to establish friendly relations with peers etc. To achieve the goals of the counselling we used some techniques and methods of cognitive-behavioural therapy, existential psychotherapy and art-therapy.

Individual work with a psychologist allows students to overcome the stress connected with changes in living conditions and the usual social interaction and to remove the psycho-emotional stress associated with the impossibility of long-term planning (due to the uncertainty of future living conditions).

The results of the studies conducted at the end of the academic year showed that the indicators of adaptation to the studying of internally displaced students were within the limits of the norm. And there could be indicated a sufficient level of their psycho-emotional well-being. In this work the main role was played by the psychological impact: individual and group counselling and trainings with elements of psychotherapy.

The main difficulties of psychological work with this category of students were connected with their comparatively high level of personal and situational anxiety, the distrust to the outside world, the desire to take a closed position in communication and some specific features of PTSD. To overcome these difficulties, we organized a process of providing continuous psychological assistance. After all, only regular, continuous interaction with a psychologist in relatively safe conditions can help to remove emotional stress, reduce anxiety and organize productive, purposeful work. Thus, in the course of work aimed at adaption of internally displaced students to college, there were held: 1) complex diagnostics of general personal characteristics and psychological state of these students; 2) the study of their past and previous living conditions; 3) regular, continuous psychological support; 4) series of training and group sessions; 5) diagnostics of the process of their adaptation to training and to other new forms of activities.

Our experience can be useful for professionals who provide psychological assistance to individuals who face the need to adapt to multiple changes in their everyday lives, and also for psychologists, who work in the sphere of higher education.

The prospect of further activities in this direction may be in developing a clear and structured algorithm of providing counselling and psychotherapeutic assistance to such students. This will facilitate the work of practical psychologists and other professionals who are involved in the process of with the socio-psychological adaptation of the freshmen to the conditions of students' life.

\section{ЛИТЕРАТУРА}

1. Березовин Н. Адаптация студентов к жизнедеятельности вуза: психолого-педагогические аспекты // Выбраныя науковыя працы БДУ, 2001. № 5. С. 11-25.

2. Гордеева Т., Сычев О., Осин Е. Опросник «Шкала академической мотивации», 2014. Том 35. № 4. С. 11-125.

3. Лазос $\Gamma$. Психологічна допомога внутрішньопереміщеним особам (на прикладі роботи 3 переселенцями з Криму). Київ: Логос, 2015. - 242 с.

4. Смаль В., Позняк О. Внутрішньо переміщені особи: соціальна та економічна інтеграція в приймаючих громадах. Київ: Логос, 2016. - 179 с.

5. Собчик Л. Психодиагностика в медицине. Практическое руководство. Москва: Боргес, 2007. - 303 с.

6. Чикина Т. Адаптивное обучение первокурсников // Высшее образование в России, 2009. №6. С. 143-145.

7. Шлаина В. Адаптация первокурсников к учёбе в ВУЗе //

Менеджмент и кадры: психология управления, соционика и социология, 2013. № 2. С. 28-30.

8. Kenneth E. \& Miller K. Rethinking a Familiar Model: Psychotherapy and the Mental Health of Refugees // Journal of Contemporary Psychotherapy, 1999. Vol. 29. No. 4. P. 283306.

9. Morina N., Akhtar A., Barth J. \& Schnyder U. Psychiatric Disorders in Refugees and Internally Displaced Persons After Forced Displacement: A Systematic Review // Frontiers in Psychiatry, 2018. No 9. P. 37-45.

10. Ricafort C. M., Rivera J. M. \& Battad B. P. Academic stress, psychological adaptation, and sociocultural adaptation of undergraduate international students in the University of Santo Tomas // 6-th World Nursing and Healthcare Conference, 2016. London. P. 125-131.

\section{REFERENCES}

1. Berezovin N. Adaptation of students to the life of the university: psychological and pedagogical aspects // Selected science prazdy BDU, 2001. No. 5. P. 11-25.

2. Gordeeva T., Sychev O., Osin E. Questionnaire "Scale of Academic Motivation", 2014. Volume 35. No. 4. P. 11-125.

3. Lazos G. Psychological assistance to internally displaced people (on the example of the work with immigrants from Krimea). Kiev: Logos, 2015. -242 p.

4. Smal V., Poznyak O. Internally displaced people: social and

economic integration in host communities. Kyiv: Logos, 2016. - 179 p.

5. Sobchik L. Psychodiagnostics in medicine. A practical guide. Moscow: Borges, 2007. - 303 p.

6. Shlaina V. Adaptation of freshmen to study at the university // Management and personnel: management psychology, socionics and sociology, 2013. No. 2. P. 28-30.

7. Chikina T. Adaptive training of freshmen // Higher education in Russia, 2009. No. 6. S. 143-145. 